\title{
JOURNAL OF A VOYAGE AROUND ARNHEM LAND IN 1875
}

\author{
C.C. Macknight
}

The journal published here describes a voyage from Palmerston (Darwin) to Blue Mud Bay on the western shore of the Gulf of Carpentaria, and back again, undertaken between September and December 1875. In itself, the expedition is of only passing interest, but the journal is worth publishing for its many references to Aborigines, and especially for the picture that emerges of the results of contact with Macassan trepangers along this extensive stretch of coast. Better than any other early source, it illustrates the highly variable conditions of communication and conflict between the several groups of people in the area. Some Aborigines were accustomed to travelling and working with Macassans and, as the author notes towards the end of his account, Aboriginal culture and society were extensively influenced by this contact. $\mathrm{He}$ also comments on situations of conflict. ${ }^{1}$ Relations with Europeans and other Aborigines were similarly complicated and uncertain, as appears in several instances.

Nineteenth century accounts of the eastern parts of Arnhem Land, in particular, are few enough anyway to give another value. Flinders in 1802-03 had confirmed the general indications of the coast available from earlier Dutch voyages and provided a chart of sufficient accuracy for general navigation, but his contact with Aborigines was relatively slight and rather unhappy. Phillip Parker King continued Flinders' charting westwards from about Elcho Island in 1818-19. The three early British settlements, Fort Dundas on Melville Island (1824-29), Fort Wellington in Raffles Bay (1827-29) and Victoria in Port Essington (1838-49), were all in locations surveyed by King and neither the settlement garrisons nor the several hydrographic expeditions that called had any contact with eastern Arnhem Land, except indirectly by way of the Macassans. Leichhardt coming north by land to Port Essington in 1845 kept well to the west after crossing the Roper River and Stuart in 1862 reached the sea not far from modern Darwin. The exploring activities associated with the unfortunate South Australian settlement at Escape Cliffs (1864-67) were all in western Arnhem Land or further west, and it was not until Cadell set about searching for a better site in 1867 that Europeans again visited eastern Arnhem Land. His account and especially that of his second-in-command, Napier, are comparable with that published here. ${ }^{2}$ Permanent European settlement at Darwin from 1869 and the steady expansion of administrative control by the South Australian authorities led to occasional voyages collecting cypress pine and maritime products, and a pastoral holding on the Goyder River was briefly occupied. However the account published here is not only among the earliest descriptions of eastern Arnhem Land but is also one of the more interesting from the point of view of Aborigines.

Although E.O. Robinson, a member of this party, sent some information about Aborigines on the Cobourg Peninsula to A.W. Howitt in $1880-81,{ }^{3}$ the whole of coastal Arnhem Land remained beyond the range of significant anthropological work until the first missionaries arrived in the area from 1916 onwards. Within ten years, W. Lloyd Warner began the field work at Milingimbi in the Crocodile Islands, which led to his justly famous book, $A$ Black Civilization (1937). The social and cultural complexity of the area and the artistic creativity of its people have attracted an enormous research effort since then. The vigorous social and cultural development of Aboriginal societies in

1 For general discussions of the conditions of Macassan contact with, and influence on Aborigines, see Macknight 1972 and 1976.

2 Cadell in South Australian Parliamentary Papers 1867/178, 1868-9/24, 79 and 79A; Napier [?1876].

3 Robinson to Howitt, 6 June 1880, 21 November 1880, 20 July 1881. Howitt Papers, La Trobe Library, Melbourne. 


\section{ABORIGINAL HISTORY 1981 5:2}

Arnhem Land today is all the more interesting because of the opportunity to trace changes over time. There is still much work to be done on the history of these societies. This document, for all its self-interest and bias, can serve as a source for that history. At the least, it shows that even if coastal Arnhem Land was relatively poorly known to Europeans a century ago, it was by no means cut off from contact with a wider world. ${ }^{4}$ In origin and objectives, the expedition described in this journal had nothing to do with Aborigines or Macassans: it was a gold prospecting expedition. Payable gold had been discovered in reefs south of Darwin in 1872 and a minor rush had developed bringing a relatively substantial addition to the Territory's European population. Although the mines continued to provide the major part of the Territory's export income for the remainder of the century, it was clear as early as the beginning of 1875 that a new field, especially an alluvial field that could be easily and cheaply worked by the miners already in the Territory would be most welcome. In January G.B. Scott, the Government Resident, reported to his Minister in Adelaide:

Unfortunately no alluvial finds of any great extent have yet been discovered. Whether they will or not is an open question. Some experienced men say Yes, some say No. If something of this kind is not soon developed I fear there will be quite an exodus of the European population and if so the country cannot progress. ${ }^{5}$

In March Scott obtained approval to supply a party of volunteer prospectors with horses and rations. ${ }^{6}$ The resulting expedition under Thomas Walker eventually reached Blue Mud Bay overland, but returned to the telegraph line on 21 October with nothing but a sorry tale, a map of its travels and a quantity of black sand thought to be from the head of the Liverpool River. When eventually analysed, the sand contained neither tin ore nor gold. The party's route was noted by the Surveyor General, G.W. Goyder, but, as he observed, the information that the country was barren and utterly worthless only confirmed previous reports. Worst of all, however, the leader Walker had been killed by Aborigines and two others of the party wounded. ${ }^{7}$

When the party with which we are here concerned was in eastern Arnhem Land a few months after Walker's party, it heard reports of the earlier party and found traces of its passage. (It is tempting to suspect some local Aboriginal help with locating the camp site and tracks, though this is not stated.) Not suprisingly, given that forty Aborigines were said to have been killed in the affray in which Walker died, news of the overland party had spread far and wide. The present journal provides good evidence on how much Aborigines knew about European exploring parties and massacres beyond the actual route of the Europeans. ${ }^{8}$

On the same day, 15 November 1875, that the Government Resident wrote to tell his Minister of the outcome of Walker's expedition, he also reported that he had lent the government cargo boat Woolner to 'a Mr Robinson and four others' to go prospecting. Wishing to appear careful, he added that he had obtained guarantees for the safety of the boat, but in the event the Minister was 'glad to find [the Government Resident] alive to the necessity of doing all in his power to develop the resources of the Territory' and recognized the need for discretionary action. The Woolner had left over two months before. ${ }^{9}$

4 The document has already been used by historians. It is extensively summarized in Berndt and Berndt (1954:92-94) and I have also used it (Macknight 1972, 1976).

5 SAA 790/1875/136. Bauer (1964:77-91) and Blainey (1969:90-96) describe the progress of the goldfields. As Blainey makes clear, the contemporary spate of discoveries in Queensland made the hope of further fields seem not unreasonable. There was also considerable enthusiasm at this time for a wide range of agricultural projects, but to no significant effect then - or later.

6 SAA 790/1875/78.

7 A rather sketchy journal of the expedition and a map is preserved in CRS Al640/1875/623. See also SAA 790/1875/586, 588; SAA 793/1876/194-6; CRS A1640/18766/25.

8 On this point, see Reynolds 1978.

9 SAA 790/1875/590. Prospecting parties continued to look for government interest and support. See, for example, SAA 790/1875/437 and $790 / 1876 / 158,367,369$. 
As the local newspaper at the time had reported, the party comprised 'E.O. Robinson, J. Lorance, Eb Francis, - Brown, Fred Arnold and a black boy'.10 Robinson was apparently the best known, at least to officialdom, and probably acted as leader. He seems to have arrived in the Territory about a year before and went on to a long and eventful career there as cattle station manager, trepanger, Customs official dealing with the Macassans and, probably most profitably, buffalo shooter and hide exporter. ${ }^{11}$ Nothing is known of the other men, nor is it clear why the present journal is written by Lorance. The destination of the party was apparently the same as that of Walker's party: the Government Resident reported that they were bound for 'a place about two hundred miles to the Eastward of Port Essington, ... it being alleged that the Aborigines in the locality obtained gold and trade therewith with the [Macassans]'. ${ }^{12}$ It is now impossible to track down the ultimate source of this rumour about gold near Blue Mud Bay, which seems to be quite wrong, but it was certainly no secret.13

The Lorance journal as we have it was apparently written up after the return of the party, though it would seem to have been based on a log kept at the time. Thus, a retrospective comment doubting Aboriginal information, which is found in the long entry for 13 October, is distinguished by brackets in the manuscript. The whole would appear to have been written out at one sitting with the handwriting steadily growing in size and confidence, and there is no reason to doubt the date of 18 December 1875 . Although expression and spelling are often a little rocky, the sense is not obscure and I have kept editorial corrections to a minimum.

Immediately after the arrival of the party in Palmerston, a brief account of the voyage, which agrees in all but a few details with the information in Lorance's journal, was provided by 'one of the party' to the local newspaper. ${ }^{14}$ On 8 January 1876 , the Government Resident forwarded the journal to his Minister in Adelaide with a covering note saying that it 'gives information relative to country we have been hitherto unacquainted with'. Two months later, it reached the Minister's office where a file was made up which determines its present location. ${ }^{15}$ From the minutes on the file cover it is possible to follow some of the progress of the journal around the Adelaide bureaucracy. The first minute is by J.P. Boucaut, Premier and Commissioner of Crown Lands, ensuring that the file was passed on to the Survevor General, Goyder, 'for his \& Bishop [Bugnion's] information'. More than three months later, Goyder noted merely that 'The route \& description of country had been laid down on Land Office plans' and the file was returned to the Northern Territory office. ${ }^{16}$

NTT, 18 September 1875:2

11 Robinson's career deserves further study. In addition to the references given by Macknight (1969:403), see also SAA 1374/ A305 and SAA PRG 247, Series 1, Little to Lewis, 1 March 1878.

12 SAA $790 / 1875 / 590$.

13 For example, over a year earlier the Government Resident had been regaled with an imaginative account of Dutch and Portuguese gold-seeking in the course of a request for the services of a boat to supply an expedition to Blue Mud Bay (SAA 1374/A324). This proposal appears not to have been realized, though it may have lain behind the two expeditions of 1875 .

$14 N T T, 17$ December 1875:2.

15 SAA 790/1876/74. The file is entitled 'Reporting return of "Robinsons" prospecting Party". I am grateful to the Archives Department of the State Library of South Australia for permission to publish this material and, as always, for friendly and efficient assistance.

16 Boucaut's minute was clearly related to the negotiations he was having in the same week with the remarkable Bishop Bugnion concerning a projected settlement of 'Russian' Mennonites in the Northern Territory. Goyder also seems to have had a personal interest in the matter. See entries in the Australian Dictionary of Biography for Boucaut, Bugnion and Goyder. There is extensive archival and other material on the incident. I am indebted to Dr J. Urry for elucidation on Bishop Bugnion and his settlers. 
Palmerston Dcbr. 18th. 1875

\author{
G.B. Scott Esq. \\ Government Resident \\ Palmerston
}

Sir

On behalfe of myselfe \& Party latyly returned from Blue Mud Bay I beg to submit to your notice the following particulars of our Expedition.

We left Palmerston on the ninth of Sptbr. 1875 \& arrived in Port Essington on the 12 th, took in a supply of fresh water \& some native blacks to serve as interpreters. ${ }^{17}$

Sptmbr. 18 left Port Essington 9 a.m. anchored at Smith Point got a supply of Geese of which there were thousands

19 anchored in Bowen straits

20 at Valencia Island found native well with water

21 experienced strong headwinds ran under De Courcy Head for shelter. Saw lots of Buffaloes on shore, on wind calming got under way again \& arrived at Sims's' Island 2 a.m.

22 shifted to Goulbourn Island, found Water about halfe a mile in land, at night had a visit from the natives with their Lubaraas, they brought some Tortoise shell to Trade, but as I did not want it, they sold some to Robinson for a knife.

The Goulbourn Islands are very poorly timbered \& very stony, the strata is a sort of conglomerate in which occur a few Quartz Pebbles;

Our water being stinking had the blacks to fill with fresh \& left in afternoon 23rd, made mouth of King River \& anchored.

Sptbr. 24th Came to Hall Point, where natives swamm of[f] to Woolner, I gave them some Tobacco when they invited us on shore telling us there were plenty Geese \& Ducks; myself \& Arnold went and were received very friendly, Lubaraas bringing us water nuts \& yams; found Game plentifull but shy; Buffaloes according to natives, very numerous in land, saw some Buffalo tracks, found country low but well timbered some trees of large dimensions, description same as around Palmerston.

Darkies shifted camp \& came near vessel where they honoured us with a grand corrobooree the lubaraas danced a very peculiar but very gracefull dance, to the accompagnment of their national instrument, a hollow piece of wood, on which they make a droning noise, but keeping exellent time.

I gave them a dish full of flour to make dampers, when several old Warriors stept forward, smell't it, took pinches and tasted it, when I made them understand it was for to eat, they seemed very much displeased with it, and retired to some sort of counsil, discussing no doubt the merits of my present, when one young warrior stepp'd forward, dipt his fingers in the flour, \& put some on his breast, a cry of delight was the result, the consil brooke up in a hurry and about halfe a minute afterwards all the men were beautifully floured allover, from top to toe when they were a deal more cordial to us.

Afterward when on[e] of our blacks made the flour into dampers for them, all clouds disappeared from their brows \& they did their utmost to please us.

The newspaper account (see note 14) says they collected 8 Aborigines. Their main skill as interpreters probably lay in a rough knowledge of Macassarese, which served as a lingua franca around the coast. For another example of a presumably Port Essington man with the same skill, Robinson noted on the Goyder River in 1885 that 'my blackboy who had been there many times before in the proas, informed me that the Macassar name for the sandy beach inside the Goyder is "Lima Toodi" [Limba Tudea or
Shell Bay]" (CRS A1640/1885/1151). 
ptbr. 25th came to Haulround Island.

" 26th had calm anchored about 8 p.m. under Cape Stuart, passed a larg[e] river opening ${ }^{18}$ \& saw what $I$ took to be the wreck of a malay Parw, on false Point.

27 Landed $^{19}$ to bake bread, had seen three blackfellows, were very shy, had great difficulty in getting near them, but induced one of them to come.

I gave him some Tobacco, and sent him to fish for us, he was unsuccessful, next I had him questioned by our blacks about water, he pointed out a place about three miles away, on going there we were joined by three more blacks, when we came to the water found it a native Well about fourteen feet deep, sunk in a hard cement, how the blacks managed to excavate it with their tools is a riddle to me.

Found Water very bad and stinking, so went back to beach, when the four blacks proposed to fetch water for us from a well further along the beach, I let them go, but keeping one as hostage, on second thought I determined to go aloag with them to hurry them up, they went a long way along the beach, around fals[e] Point when they led about halfe a mile in land I noticed that they allways tryed to get behind me which I would not allow, on coming near well, saw a large camp of bla[c]ks at some distance; While one cleared out the Well, the two others went to the camp, when I saw lubaras \& pikaninnies leaving in the opposite direction then blackfellows kept arriving by twos and threes, me sitting in the shade on the foot of a tree; They got very impertinent asking for tobacco, which I refused to give, when they tryed to take the pipe out of my mouth; ten or twelfe gradually worked themselfes behind me, when the idea stru[c]k me that it was getting rather warm, having two revolvers \& a splendid rifle, I did not think much of it, but thought discretion the better part of valour; so I jumped up, turned the muzzle of my rifle towards them \& gave them to understand there was danger of it going of [f], if they did not move out of the road; I also pointed one of my revolvers toward them, they seemed perfectly to understand the qualytys of both, for they instantly cleared to either side of range, then there was a great yabber amongst them, apparently trying to encourage each other to attack me, by this time there was a little water gathered in [the] well, so I ordered my first a[c]quaintance, to fill the buckett \& carry it, me following to beach. As soon as they saw me leave there was a great $\operatorname{com}[\mathrm{m}]$ otion, some of them stept in my way when I laughingly poked them in the ribs with my rifle, (muzzle) finger on trigger, they opened out \& I walked through keeping rifle pointed, at them, they hung back \& then the nigger, carrying buckett, refused to move any further, so I went out the beach by myselfe, where I met two of the party who had become rather uneasie on my account, we returned to the well \& found the niggers occupied in taking the hoops of [f] the cask, but on seeing us they cleared, taking hoop \& pannikin with them.

Afterwards we heard from the blacks that those were the worst niggers on the whole coast, surprising Malay Praws killing \& eating the crews \& breaking up the vessel for the iron, we found some good Turtle spears in their possession also a Malay axe \& tomahawk, the country flat but pretty fairly timbered.

ptbr. 28th came to Crokodile Island

" 29 Went into an inlet laid ship close to a native Well ${ }^{20}$

" 30 Emptied old Water \& filled with fresh

Island seems very rich soil, low lying but very prolific growth and luxuriant in al[1] native plants, splendid timber, saw fresh tracks of natives on northern side but did not fall in with any. 
Octbr. lth. Left daylight, wind dead ahead came [to] Point Guy, found strata all on its flat Octbr. 2th Off daylight, on rounding Point Guy saw five big canoes, entered Cadell straits.

" 3 " made about five miles more last night, beat with a strong Tide in our favour; found Cadell Straits passable for largest vessels, six to seven fathoms in Channell, but a few shallow banks, if those were properly marked out on chart, the biggest ships could pass in safety. All the Malay Praws are in the habit of passing through them; the Main land appears very low, but Elcho Island is undulating with little rises, Water Plentyfull the valeys black soil fine growth of timber but open forest strata sandstone.

4th Saw more canoes, came to one of Cunningham Islands, composed of white sandstone having nearly the appearance of Quartz.

Octbr. 5th. Came to Inglis Island, went ashore and met an old lubaraa who took us right across; the Island is very high, from three to four hundred feet composed of a slaty sandstone laying flat, land barren \& stony.

" 6" Darkies coming on board told us about four white men with lots of horses were camped about three sleeps from Arnhem Bay, Wanted them to take us to them they promised to do so, but in morning left in a great hurry. ${ }^{21}$

" 7 " Came near Cape Wilberforce, on carrying away sail, returned to a little Bay for shelter

" 8 " Lots of darkies come on board, got them to bring us water. Crossed Peninsula found strata consisting of white sandstone, natives very friendly, will work for slight remuneration, the finest body of darkies I have seen, not tattoed circumcised are all this side Hall Point ${ }^{22}$

left at noon \& came to Melville bay where we found strata composed of Granite, found Melville Bay a good land lo[c]ked Harbour.

" 9" Came around Cape Arnhem, found a terrible Tide rip some of our darkies who had been down here before with the Malays, cautioned us to be silent and not speak if any Macasser men (Malays) should appear, a good many Praws have been lost in this tide rip, which looked more like a boiling cauldron than an agitated sea. Got safely through \&c anchored on other side in a little bay.

" 10 " Came to Carricaglan, ${ }^{23}$ past left hand harbour \& came to an enormous land lo[c]ked sheet of Water of great depth, mountainous to the West, to the north west low land heavyly timbered, saw swarms of ducks, returned to left hand branch ${ }^{24}$ and went up about eight miles

" 11 " Came about 6 miles further and found Water getting shallow which sofar was from three to four fathoms.

" 12 " Filled Water casks \& anchored in centre of harbour

“ 13 " Started overland to Arnhem Bay to solve the mysterie about the white men. found Buffalo tracks, some quite fresh. Splendid Grazing country, well watered fine description of timber, water every three or four miles, plenty of permanent creeks a fine big river ${ }^{25}$

21 The newspaper account says that here "they first heard of the Walker and Marshall affair. One native mentioned white people in the country looking for gold, and was asked to take the party there, which he promised to do, but in the morning he was nowhere to be found: this was supposed to be about three days' journey from the scene of the outrage.' The four surviving members of Walker's party had started back from a point southwest of Arnhem Bay on 4 September.

22 From later observations, this is accurate. The division between circumcising and non-circumcising occurs about Maningrida.

23 The newspaper account has Karakagion. This is presumably a distant corruption of the Macassan name for Port Bradshaw, Karakaraenga (Macknight 1976:96).

24 That is, Holly Inlet.

25. Probably the Cato River. 
larger than the Adelaide emptying into Arnhem Bay from the east. Rocks are Granite, fine undulating country, black soil, seems not subject to inundations, river and creek channels being deep and wide enough to carry of $[\mathrm{f}]$ all storm waters, Kangaroos Co[clkatoes white Pigeons native Compagnions Ibis \& Turkeys plenty full, also saw one alligator. On coming near Arnhem Bay, found it surrounded by Plains of from four to six miles wide, met darkies who had heard of us from adjoining tribes, came with their families \& camped near us. One very intelligent fellow with a broken leg gave us a deal of information he had been to Maccasser \& Singapore with the Malays and had a great admiration for those places, knew the points of the compass in malay and even spoke a few words of english, he told us of the whites we had heard of and said it was about [a] three day journey to the south west [to] where they had been, had seen them himself, there had been a great fight between the blacks and them two whites had been killed and in return they had shot fourty blacks, he had lately returned from there where he had broke[n] his leg in escaping from hostile blacks ${ }^{26}$ (My believe now is that he was one of the party attacking Walker \& party and broke his leg escaping from them) he advised us to go by water and said he was very sorry to have his leg broke[n], or he would go with us, about the whites, he told us they had lots of Horses, Pi[c]ks, Shoffels, Tin Dishes eating bread and drinking Tea out of Pannikins. ${ }^{27}$ As there was not the slightest indication of aurifirous country, I concluded to return and make Blue Mud Bay, made a present of tobacco and some empty tins to them and returned; I found this the finest part for a Cattle station I have seen in all Australia being covered with a fine silky Grass very thick, almost like an old country meadow in the lower grounds while the little rises are covered with Kangaroo Grass. ${ }^{28}$

We returned to vessel and left for Blue Mud Bay on

br. 20th on coming down harbour saw some blacks with canoes who were very frightened of [us], could not get near them our darkies wanted to hunt them, having an old score against them. four Prt. Essington blacks coming with a Malay Praw to here, the skipper of the Praw sold them for a quantyty of tortoise shell to those niggers, they making a feast of them, knowing the relations of the devoured being with us, they kept clear.

br. 23th Lost anchor, cable being cut by coral. had darkies diving several days but could not recover it made an achor out of $\mathrm{Pi}[\mathrm{c}] \mathrm{ks}^{29}$

26 The journal of Walker's expedition explains some of what happened. Despite an attack in central Arnhem Land on 17 June, in which Bridson was wounded in the hand, the party reached the southern end of Blue Mud Bay on 7 August. On 9 August, some distance south of the bay, they 'Started this morning from about 30 natives who had been very friendly the day previous, we making them small presents they followed us unperceived, entered the camp and speared two of our party, wounding them very severely, we beat them off ... having travelled a long distance we had no thought of natives following us.' The attack occurred about 11 p.m. and Walker, the leader, died early next moming. Marshall, though badly wounded and in much pain, eventually got back to the telegraph line. A mile or so away from the scene of the attack, on 12 August, the author of the journal notes, 'Natives all round us during the night. They don't like to come too close to the rifle tried to burn us out in afternoon', and ten days later, 'Natives about all last night going as usual after the horses they surrounded me about a mile from the camp intending to kill, had the bridle on one of the horses, fired my revolver at them and galloped into camp and got the rifle to bear on them one shot was enough they cleared' (CRS A1640/1875/623). It is not hard to believe that forty Aborigines were shot.

27 The newspaper account adds that the Aborigines said 'that the quarrel arose in consequence of their not being able to understand one another.'

28 In 1885 on the Goyder River, E.O. Robinson recalled that 'Some ten years ago I walked from the Gulf near Sir Rodericks Rocks to Arnheim Bay and at the end of the dry season, November, no rain had fallen "Struck a fine fresh water river running into Arnheim Bay." There are several openings left in the coastline in Arnheim Bay and I dont think any one so far has looked at them, except the Malays. I shall endeavour to get some information from them when they come down' (CRS A1640/1885/1151). The newspaper account says the Aborigines dived for two days in search of the anchor. 
“ 28 " In consequence of delay are short of water, serve allowance had landed Cape Shields, found no water; not aurifirous; find Blue Mud Bay very shallow, landed and sunk wells but without success. went to range marked in chart, ${ }^{30}$ found some Quartz Pebbles, saw cement on beach possible for Gold to be here

29 Ashore again, found no water rounded Point southward and saw what looks like a river opening

30 Went up river ${ }^{31}$ with dingy followed right hand branch $^{32}$ and found Water on very head about 15 miles from entrance, string of waterholes, must be big creek in wet season Country flat with little rises at distance deep chocolade soil

Octbr. 3lth Filled breaker \& water bags and returned to vessel which had come up about 10 miles found water in a swamp but a little bra[c]kish. ${ }^{33}$

Nvbr. Ith \& 2nd Filled Casks \& went up river about six miles

" 3rd Left with tide and came three or four miles further when stopt by a rocky bar, river aparently closed up ${ }^{34}$

" 4 " Went up river on foot, splendid stream, pitty bar stops navigation. found an old camp of whites, many horse tracks. darkies consider tracks to be three or four months old, found a small clorodine bottle, empty, must have been Walker and party. ${ }^{35}$

5 Started with dingy up river leaving Arnold and lubaras aboard, came about ten miles when river was blo[c]ked up with dead timber and network of Palms. Left dingy in charge of one man and two blacks, travelled about ten miles west over sandstony ranges, strata all flat no signs of any minerals camped on a water hole

6 Went about four miles and came to river again, which makes a great half circle travelled about six miles further up river bank which goes to the N.W. ${ }^{36}$ but seeing no indication of auriferous country in river wash, which must have come a long way down country, concluded to return, came back to dingy toward night splendid River, running very rapid, country having a large fall, some very high land towards head of river must come a long way, shot lots of Kangaroos and Ducks river valley not very wide sides covered with heavy wash long way up. Great floods apparently coming down in wet season, river higher up clear of obstructions navigable for boats but strong current

Nvbr. 7th Came back to vessel, (found tracks of one horse high up river) this morning found tracks leading northward across a bar in river, on returning heard shots fired in direction of vessel when arrived, Arnold told me, had been surrounded by about sixty blacks who shook their spears at him, filled Water casks and mad[e] ready for starting

30 Probably the Coast Range about $5 \mathrm{~km}$ inland from the coast due west of Blue Mud Bay. The chart was no doubt derived from that of Flinders, who vaguely indicates high ground here (Flinders 1814: plate XV). The most useful modern maps for following the expedition's movements in the Blue Mud Bay area are the Australian Topographic Survey Series R 621 at 1:100,000 scale, sheet 6070 (Blue Mud-Bay) and sheet 6071 (Koolatong).

31 Walker River.

32 Marura River. All the distances given for river travel are slightly exaggerated.

33 A breaker is a small water-cask used on shipboard. The newspaper account says that the Woolner went up

33 A breaker is a small water-cask used on shipboard. The newspaper account says that the Woolner went up the river 12 miles to the fork where the right hand branch went off. There are several swamps near the junction of the Walker and Marura Rivers.

34 The newspaper account makes it clear that the Woolner was taken up 'four miles further' to the bar.

35 Chlorodyne was a patent medicine containing chloroform. It enjoyed great vogue as a pain-killer. The newspaper account adds detail: 'About two miles beyond this. [bar] the party found Marshall's camp, their tracks seemingly from the south. The overland party had been down the river and back again. Traced them across the river going north, about four miles above camp.' This was accurate bushcraft. The journal of the other party records that on 25 August they 'struck a large river running East North East. We ran it down to cross it till we came to salt water had to run it up to get on the other side'. The next day, they 'still run the river up and crossed two branches' (CRS Al640/1875/623).

36 They probably reached Mount Ranken in the Bath Range. 
Nvbr. 8th Saw a few blacks, but kept their distance.

Saw a few alligators

9 Squally, not save to go into shallow Bay so stopt.

10 went further down headwind, went to ranges where I had seen Quartz previous, found them to consist of Granite with a layer of about twenty feet thickness of the white sandstone having the appearance of Quartz. Country about lower part of river splendid for rice plantations, very little cutting would irrigate hundreds of square miles in parts there are thousands of acres of black soil, near the seacoast I found some large salt pans looking like water at a distance, on coming near they have the appearance of a frozen lake covered in parts with 3 an[d] four inches of salt, white as snow.

11 Went out at daylight sailed northward an[d] entered another large river, saw plenty of alligators in this river some of enormous size ${ }^{37}$

13 . Found a large bra[c]kish lagoon swarming with Game, disturbed some Gins who were gathiring nuts, they hooked it and our blacks after them on a lubara hunt, but they returned unsuccessfull

14 Went up river about 12 miles and came to branches, ${ }^{38}$ stopt, Water perfectly fresh. Our darkies grumble and want to go back home

15 Our darkies went to lagoon again, heard some niggers holler lefthand side ${ }^{39}$

16 Started up what appeared biggest branch but notice strongest current in smallest. ${ }^{40}$ Went with dingy about eight miles when it divided in numerous small branches clomb tree and had a look around; saw some high land 10 to 15 miles to the southwest, ${ }^{41}$ country all flat with channels of fresh water through it splendid Grassland but rather low could see no flood marks, if dry, would be magnificent country for any purpose excepting Gold digging. Saw very heavy timber, larger trees than I have seen anywhere else in the N.T. Returned to Woolner

17 Went up right hand branch ${ }^{42}$ with dingy and found it a large river alive with alligators right hand bank rising ground, a sort of rotten honey combed rock, left hand flat, deep black soil heavyly timbered but well grassed went above influence of tide and marked tree with initials and date went a few miles further and found river blo[c]ked up with dead timber, stream about fourty yards wide and on rapids from 3 to 4 feet deep seems to come from N.W.

18 Jack in morning came aboard with news that four of our darkies had left to go back to Port Essington by land. Am afraid will never get back. ${ }^{49}$

19 Came to Morgan Island

20 Arrived at $\mathrm{Bi}[\mathrm{c}]$ kerton Island, saw what looked like Quartz at a distance went and found it conglomorate mixed with Quartz Pebbles, splendid Island for Water, nativ[e]s very friendly fishing for us and bringing us Water and ballast, for which I rewarded them with rice and tobacco with which they were highly pleased; I find all the coast blacks in

37 Koolatong River. The newspaper account adds that "There was a bar at the entrance, with about a fathom of water on it, when it deepened to three or four fathoms all the way. The water was fresh about six miles up.'

38 This seems to be the Maidjunga River junction.

39 The newspaper account mentions that the party was trying to discover more information 'about the affray between the whites and the blacks' as well as searching for gold.

40 It is unclear whether they went further up the Koolatong River or followed the Matta Murta River southwards, but the latter is perhaps more likely.

41 Perhaps the Mitchell Ranges.

42 This seems to have been the Maidjunga River.

43 On 26 February 1877 Charles Levi at Port Essington wrote to John Lewis, 'Of the darkies who went to Blue Mud Bay, three returned overland out of four one speared - the others returned in the boat' (SAA PRG 247, Series 9). 


\section{ABORIGINAL HISTORY 1981 5:2}

a slight degree civilised, having been from time immemmorial connected with the Malay fishermen, ${ }^{44}$ working for them and in return getting paid by them in kind, as tobacco rice spearheads canoes \&cc they all speak Malay and look forward to their arrival with joy. In all the sheltered nooks along the coast there are beacon[s] stuck and on asking the blacks what they are for, they tell you with pride, Maccasser man sit down, they have their regular stations and there must be some hundreds annually come here for the Trepang fishing, I found their boiling places all along the coast what I can make out from the blacks they arrive in January and leave in April or May. ${ }^{45}$

21 Left for homeward bound sailed along Grote Island, composed of Granite looking very stony, thought it not worth while to land

22 \& s.f. Rounded Capes Arnhem, Wilberforce, through Cadell straits, landed Elcho Island found it beautiful land fit to grow anything, fertile look well watered, Landed at several places along coast, went up some rivers ${ }^{46}$ but saw no indication of Gold any where, found all the country far superiour to land about Port Darwin stopt a cupple of days at Goulburne Islands came to Smith Point landed remainder of our niggers left next day an[d]

13th returned wit[h] fair wind last Monday to Palmerston.

Thanking you for you[r] kind assistance given

\section{I remain yours very devoted}

J. Lorance.

AUSTRALIAN NATIONAL UNIVERSITY

\section{BIBLIOGRAPHY}

Bauer, F.H. Historical geography of white settlement in part of northern Australia Part 2. The Katherine-Darwin region, (C.S.I.R.O. Division of Land Research and Regional Survey, Divisional Report No 64/1). Canberra, 1964.

Berndt, Ronald M. and Catherine H. Berndt. Amhem Land its history and its people Melbourne, 1954.

Blainey, Geoffrey. The rush that never ended Melbourne, 1969, 2nd edition.

CRS. Material held in the Australian Archives, Canberra. Commonwealth Record Series A1640 oonsists of Correspondence dockets, N.T. series, 1868-1910. (For its history see Aboriginal History 1, 1977:109-10. The files used were originally part of SAA 790).

Flinders, Matthew. A voyagre to Terra Australic London, 1814, 2 vols and atlas.

Macknight, C.C. The Macassans: a study of the early trepang industry along the Northern Territory coast. Ph.D. thesis, Australian National University, Canberra, 1969.

44 For more detail on the information about Macassans in this entry, see Macknight (1976). I believe the Macassan vovages began very roughly about $1700 \mathrm{~A}$.D.

40 The newspaper account adds some detail. 'Arrived at Bickerton Island. The Port Essington natives said the whites had been living at the "Wakea" a long while ago. At Bickerton Island found that "Wakea" was Malay for the Roper River.' In fact, Wakea seems to be a Nunggubuyu word meaning south. It is reported as a name for the Roper River in several sources (Macknight 1976:61). Possibly the author of the newspaper account assumed that Wakea was 'Malay' because it was known to the Aborigines brought from Port Essington, some of whom, as we know, had been on the praus. The Macassans did, occasionally, adopt Aboriginal place-names (Macknight 1972:291). A close reading suggests that the Port Essington Aborigines had only a vague knowledge of Wakea, which they may have picked up anywhere, and presumably through the Macassarese lingua franca the friendly Aborigines on Bickerton Island provided more details. Whatever the precise course of events, it is a good illustration of the communication made possible by a lingua franca. The mention of the whites on the Roper River may refer to the parties associated with the construction of the Overland Telegraph in 1872, or more probably, to a visit by Captain Marsh in the government vessel Flying Cloud in August 1875 (SAA 790/1875/439). This trip was to supply the party visiting justice upon the Roper for the murder of C.H. Johnston earlier in the year.

46 The newspaper account mentions the King River 'which proved to be only a salt water inlet'. 
—. 'Macassans and Aborigines', Oceania, 42, 1972:283-321.

- The voyage to Morege': Macassan trepangers in northem Australia Melbourne, 1976.

Napier, Francis, Notes of a voyage from New South Wales to the north coast of Australia [?Glasgow], [?1876].

NTT. Northern Terrilory Times and Gaette.

Reynolds, Henry " Before the instant of contact": some evidence from nineteenth-century Queensland', $A$ boriginal History, 2(1), 1978:63-69.

SAA. Material held in the Archives Department of the State Library of South Australia.

Series 790. Correspondence received in the office of the Minister controlling the Northern Territory: $1868-1910$.

Series 793: Out letter books of the office of the Minister controlling the Northern Territory: 1868-1910.

Series 1374. Incoming correspondence of the Government Resident: 1870-1910.

PRG 247. Private Record Group 247, Lewis Papers.

\section{ABORIGINAL HISTORY AND HISTORY' '82}

HISTORY' 82 is the first general conference organised by the Australian Historical Association. It will be held over three days at the University of New South Wales, 26-28 August 1982. Some twenty specialist historical organisations will hold meetings and co-operate in planning the program. Arrangements for presenting papers will be largely in the hands of the relevant specialist organisations.

Sessions will cover a wide variety of topics and themes, and various symposia and plenary sessions are planned. Historical geographers, oral historians and specialists in African, Asian and Pacific history will make contributions, and there will be reports on the progress of Australia 1788-1988: A Bicentennial History.

The co-convenors of the HISTORY ' 82 conference are Dr Heather Radi of Sydney University and Dr Frank Farrell of the University of New South Wales. News of arrangements will appear in coming issues of the Australian Historical Association Bulletin. For general information write to: HISTORY '82, School of History, University of New South Wales, P.O. Box 1, Kensington, NSW 2033.

ABORIGINAL HISTORY will occupy a full day's program at the conference. Three groups are co-operating to plan the sessions: the Interim History Committee of the Australian Institute of Aboriginal Studies, the Editorial Board of Aboriginal History and the Working Party of Aboriginal Historians formed at the February 1981 Bicentennial History conference. The planning committee hopes to structure the program around two themes: 'Family and community in Aboriginal society' and 'Language, method and the past', and will welcome papers (either 15 minute reports or 45 minute presentations) related to these themes. If you would like to propose a topic for consideration, or wish further information about the Aboriginal history section of HISTORY '82, please write to: Dr Isabel McBryde, Department of Prehistory and Anthropology, Faculty of Arts, Australian National University, P.O. Box 4, Canberra, ACT 2600. 


\section{AUSTRALIA 1788-1988: A BICENTENNIAL HISTORY}

Since the last report in this journal (1980 4:2), the bicentennial history project has moved from the exploratory period to the second and final stage of writing and research. All nine books in the series now have editors, who are responsible for nominating contributors, determining the final shape of the books, and presenting completed texts and illustrations to the general editors, Ken Inglis and Frank Crowley. The books will be published before 1988, so as to influence discussion of Australia's past during the bicentennial year. Aboriginal history will feature prominently throughout the series. Two books will include large sections on Aboriginal Australia before European settlement. AUSTRALIA TO 1788, edited by John Mulvaney and Peter White, will be mainly about Aboriginal Australia to 1788. One fifth of the book will consider Asian and European arrivals. In May 1981 a meeting at the ANZAAS Congress elected a working party to shape the Aboriginal segment of this volume. The group, comprising Sandra Bowdler, Jim Bowler, John Clegg, Eve Fesl, Sylvia Hallam, Marcia Langton, Isabel McBryde, John Mulvaney, Peter White and Michael Williams, subsequently proposed that the Aboriginal segment should be in two parts: the first will deal with 'Humans and landscapes', Aboriginal societies from Pleistocene origins to the time of European contact; the second and longer section will discuss diversity and unity in Aboriginal society around the time of European colonisation. In order to stress the wide-ranging diversity among Aboriginal societies two hundred years ago, most of the 1788 'slice' will consist of accounts of Aboriginal societies (language group or other appropriate unit) from different parts of the country. Each chapter will incorporate both Aboriginal and European accounts of that society, its technology, subsistence, cosmology, languages, art, drama, music and relationships with the land.

In the Reference Section of the project, the HISTORICAL ATLAS, edited by Jack Camm and John McQuilton, will include some fifteen pages on traditional Aboriginal life and prehistory. John Clegg, who is advising the editors regarding the Aboriginal section, is currently seeking ideas and information which might be included.

The Atlas will include large and small scale maps, as well as illustrations, photographs, drawings, etc.). Each large double page will be self-contained and will include an explanatory and analytical text. The following suggestions for inclusion are being considered, but no decisions have yet been made. John Clegg and the editors will welcome further suggestions, or ideas which could be incorporated into any of the following:

Map of Australian languages, along with local linguistic situations.

Archeological sites for various time brackets, analysed according to type. To be accompanied by archaeological sections, illustrations and text.

Regional art styles, both rock art and art mobilier, with illustrations of the various styles.

Local maps of land ownership, to show the complexity of Aboriginal relationship to the land. Names and significant site locations to be included where appropriate.

Environmental changes through time.

Trade and exchange networks at 1788 (or thereabouts).

The Atlas also has a bulletin, entitled Australian Historical Geography, which will welcome notes and discussions concerning the mapping of prehistoric or recent Aboriginal situations (e.g. how do we deal with the fact that tightly defined borders are a rare phenomenon?).

FOR FURTHER INFORMATION about Australia to 1788, write to John Mulvaney, Department of Prehistory and Anthropology, Faculty of Arts, ANU or Peter White, Department of Prehistory and Anthropology, University of Sydney. For the Atlas write to John Clegg, Department of Prehistory and Anthropology, University of Sydney. And for information about other books or the series generally, write to Stephen Foster, Assistant General Editor (Section A), Bicentennial History, Research School of Social Sciences, Australian National University, P.O. Box 4, Canberra, ACT 2600, or John McQuilton, Assistant General Editor (Section B), School of History, University of NSW, P.O. Box 1, Kensington, NSW 2033. 